\title{
A DCOR-BASED NPD PROCESS REDESIGN APPROACH WITH GROUNDED THEORY EVALUATION
}

\author{
C. Ou-Yang ${ }^{1}$, I.H. Yin ${ }^{1} \&$ Y.C. Juan ${ }^{2 *}$
}

\section{ARTICLE INFO}

Article details

Submitted by authors 18 Jun 2018

Accepted for publication 3 Jul 2019

Available online $\quad 30$ Aug 2019

Contact details

Corresponding author

ycjuan@mail.mcut.edu.tw

Author affiliations

1 Department of Industrial Management, National Taiwan

University of Science and

Technology, Taipei 10607, Taiwan, Republic of China

2 Department of Industrial Engineering and Management, Ming Chi University of Technology, New Taipei City 24301, Taiwan, Republic of China

DOI

http://dx.doi.org/10.7166/30-2-2008

\section{ABSTRACT}

This research proposes a benchmarking-based process redesign approach for a new product development (NPD) process. The proposed method compares the semantic similarities of the design activities in the as-is NPD process with the activities in the design chain operations reference-model (DCOR). Then a design structure matrix (DSM) is employed to streamline the redesigned NPD process and form a to-be NPD process. Finally, grounded theory is used to evaluate the to-be NPD process according to five key performance indicators and to identify the pros and cons for the redesign changes. An unmanned aerial vehicle (UAV) NPD process is used for case study and the results show that the to-be UAV NPD process is more effective than the as-is UAV NPD process.

\section{OPSOMMING}

Hierdie navorsing stel 'n maatstafgebaseerde proses voor vir herontwerpe binne die nuwe produk ontwikkelingsproses (NPO). Die voorgestelde metode vergelyk die semantiese ooreenkomste van die ontwerpsaktiwiteite in die huidige NPO-proses met die aktiwiteite van die ontwerpsketting bedryfsverwysingsmodel. Daarna is ' $n$ ontwerpstruktuur matriks toegepas om die voorgestelde NPO-proses meer vaart belyn te maak. Laastens word gegronde teorie gebruik om die voorgestelde NPO-proses te evalueer volgens vyf sleutel verigtingsindikators en om die voor- en nadele van die herontwerpveranderinge te identifiseer. ' $n$ Onbemande lugvaartuig NPO-proses is gebruik as ' $n$ gevallestudie en die resultate toon dat die om-te-wees NPO-proses meer effektief is as die soos-dit-is NPOproses.

In recent years, research on product development has focused on how to redesign a new product development (NPD) process to improve R\&D performance [1, 2]. Business process improvement (BPI), business process reengineering (BPR), and benchmarking or reference models are methods that have commonly been used to improve the business process, and each of them has its own characteristics [3]. BPR concentrates on process innovation, resulting in the largest change with the highest risk in implementation. Benchmarking or reference models pursue the improvement by learning others' advantages and preserving the original organisational characteristics. Since it has models for reference, the risk of implementation is smaller, the adoption is faster, and the process logic is also better [4]. Therefore, this study adopts the reference models to improve the NPD process.

This paper proposes a NPD process redesign approach based on the design chain operation referencemodel (DCOR). DCOR has been developed and released by the Supply-Chain Council (SCC) to provide a complete design chain analysis framework for reference [5]. This research first proposes a semantic similarity analysis approach to identify the analogy of activities and input/output between DCOR and the as-is NPD process. A mapping table is constructed to represent the analysed results. The next step is to design the process logic of the NPD process according to the generated mapping table and the logical relationships of the activities from DCOR. The design structure matrix (DSM) approach is used to analyse and adjust the activity sequence to reduce the overlapping and iterative 
phenomena among the activities [6]. Finally, grounded theory (GT) is applied to verify the effectiveness of the to-be process.

\section{RELATED WORK AND PROBLEM DESCRIPTION}

In this section, the concepts of DCOR, semantic similarity and WordNet, DSM, and GT are explained. The problem description about how to redesign the as-is NPD process by referring to the DCOR model will be also specified.

SCC released the DCOR for product development [5], the framework of which is depicted in Figure 1. Five basic management processes - Plan (P), Research (R), Design (D), Integrate (I), and Amend (A) - are used at Level 1 to define the scope and content of the design chain operations. Level 2 classifies the management processes $\mathrm{R}, \mathrm{D}$, and I into process categories. Level 3 decomposes the processes from Level 2 into process elements. It can be seen that DCOR provides reference information for each element, such as the input/output, performance metrics, and best practices. Moreover, DCOR has five key performance indicators: reliability, responsiveness, cost, flexibility, and assets. Their performance attributes are defined as follows:

- $\quad$ Reliability: The performance of the design chain in delivering product stability and process data integrity.

- $\quad$ Responsiveness: The speed at which a design chain provides products to the customer.

- $\quad$ Flexibility: Time to change a product design after it has been released to operations.

- $\quad$ Costs: The costs associated with operating the design chain.

- Assets: The effectiveness of an organisation in managing assets to support design chain operations, including the management of all assets - fixed and working capital.

DCOR was applied to multi-agent system development for the cooperative activities in NPD processes and original design manufacturing [7, 8]. Lyu and Chang [9] provided a methodology based on DCOR to standardise the management process for a product development project and to enable integration in the mould industry. Wu et al. [10] applied DCOR as a reference for developing a collaborative design chain system for the motorcycle industry, and Aniyan and Pramod [11] employed DCOR as a product development process to enhance quality function deployment in forging.

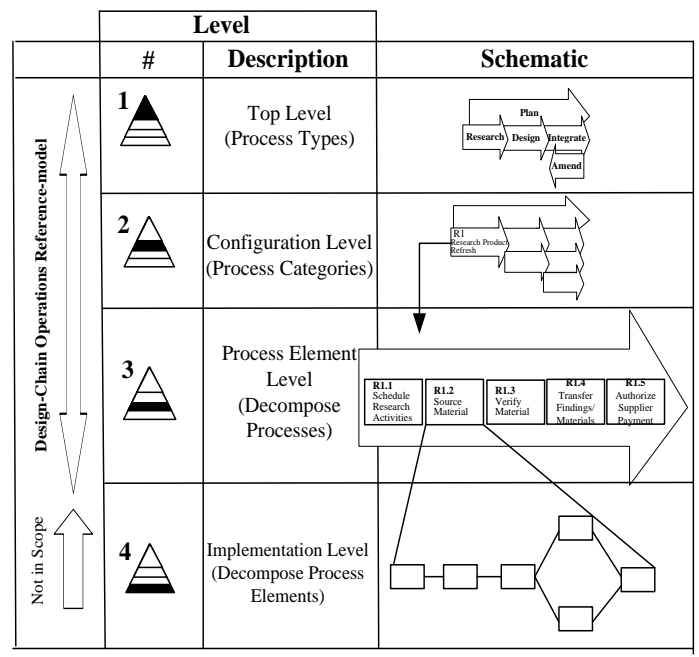

Figure 1: DCOR framework

WordNet, a large lexical database of English, is the product of a research project at Princeton University [12]. In WordNet, nouns, verbs, adverbs, and adjectives are organised according to a variety of semantic relationships into synonym sets (synsets), each representing one distinct concept $[13,14]$. Synsets are interlinked using conceptual-semantic and lexical relationships. WordNet's structure makes it a useful tool for computational linguistics and natural language processing [15]. Zili et al. [16] applied the graph-based algorithms of WordNet to measure semantic similarity and relatedness in lexical semantics. Juan and Ou-Yang [4] modified the data dictionary of the synonym 
weight and business process gap analysis (BPGA) approach to deal with naming logical problems, and Patwardhan et al. [17] evaluated a variety of measures of semantic relatedness as applied to word sense disambiguation by carrying out experiments using WordNet.

The DSM has three basic building blocks for describing the relationships among system elements: parallel (or concurrent), sequential (or dependent), and coupled (or interdependent). They solve iteration, overlapping, decomposition and integration, and convergence problems [18]. To increase the ability of design planning in architecture/ engineering/construction, Pektas and Pultar [19] provided a parameter-based design structure matrix as a process modelling and system analysis tool for building design. Lambe and Martins [20] presented an extended design structure matrix - a new diagram for visualising processes for solving multidisciplinary design optimisation problems in architecture. And Yassine [18] used DSM to solve the complex relationships among both people and tasks in the design and development of engineering products.

GT is an inductive research method. In fact, it has a few issues that have changed since its publication in 1967 by Glaser and Strauss [21]. At that time, they emphasised that researchers must pay special attention to their 'theoretical sensitivity', or the relevance of categories as they emerge from data comparisons. The newer version of GT, presented in 1990 by Corbin and Strauss [22], has as its main purpose the development of a constructive theory to emphasise the interactions of research purposes, science, and phenomena. Egan [23] proposed that an effective interview should be lengthy at the beginning stage of a study, and then more specific and focused on the topic of interest in the final stage. This research follows Egan's procedure for collecting data with inductive inference. However, GT was applied to various aspects, especially those for abductive logic in the research design process [24, 25]. Singh and Krishnan [26] applied Egan's framework to assess the impacts on the leadership behaviour of managers from several perspectives.

To redesign the as-is NPD process by referring to the DCOR model for obtaining the to-be NPD process, four issues should be emphasised in this research:

1. How to analyse the semantic similarity between the constructs in DCOR and the as-is process.

2. How to redesign the logical sequence of the as-is NPD process by referring to DCOR.

3. How to modify the redesigned NPD process to reach a more efficient to-be NPD process.

4. How to prove the effectiveness of the to-be NPD process.

\section{THE PROPOSED APPROACH}

Figure 2 illustrates the framework of the proposed four-step approach. First, the mapping relationship of activities in DCOR and the as-is NPD process is clarified via semantic similarity analysis. Next, the as-is NPD process is redesigned according to the process logic of DCOR, based on the activity mapping relationship. Third, the to-be NPD process is derived by adjusting the redesigned NPD process with a DSM method to make it more efficient. Finally, the to-be NPD process is evaluated and verified by a GT method.

\subsection{Semantic similarity analysis}

As shown in Table 1, the name of activities in DCOR has two parts, verb and object, as in the as-is NPD process. For each verb and object in DCOR, a semantic similarity tree (SST) was constructed based on the WordNet database. As shown in Figure 3, the degree of synonymity built into the SST was divided into five levels, with weights between 0.2 and 1 , where 1 represents words that are exactly the same; 0.8 stands for synonyms; 0.6 means that the same meaning can be found in some expanded nouns; and 0.4 and 0.2 stand for the fourth and fifth levels, with low semantic similarity.

Table 1: Verbs and objects in the name of activities in DCOR

\begin{tabular}{|c|c|c|c|}
\hline $\begin{array}{c}\text { DCOR's } \\
\text { code }\end{array}$ & Process element on DCOR & Verbs & Objects \\
\hline R2.1 & Receive \& validate request & Receive, Validate & Request \\
\hline R2.2 & Schedule research activities & Schedule & Materials \\
\hline R2.3 & Source materials & Source & Materials \\
\hline R2.4 & Verify materials & Verify & $\vdots$ \\
\hline$\vdots$ & $\vdots$ & $\vdots$ & Plans \\
\hline PI.4 & Establish \& Integrate Plans & Establish, Integrate & \\
\hline
\end{tabular}




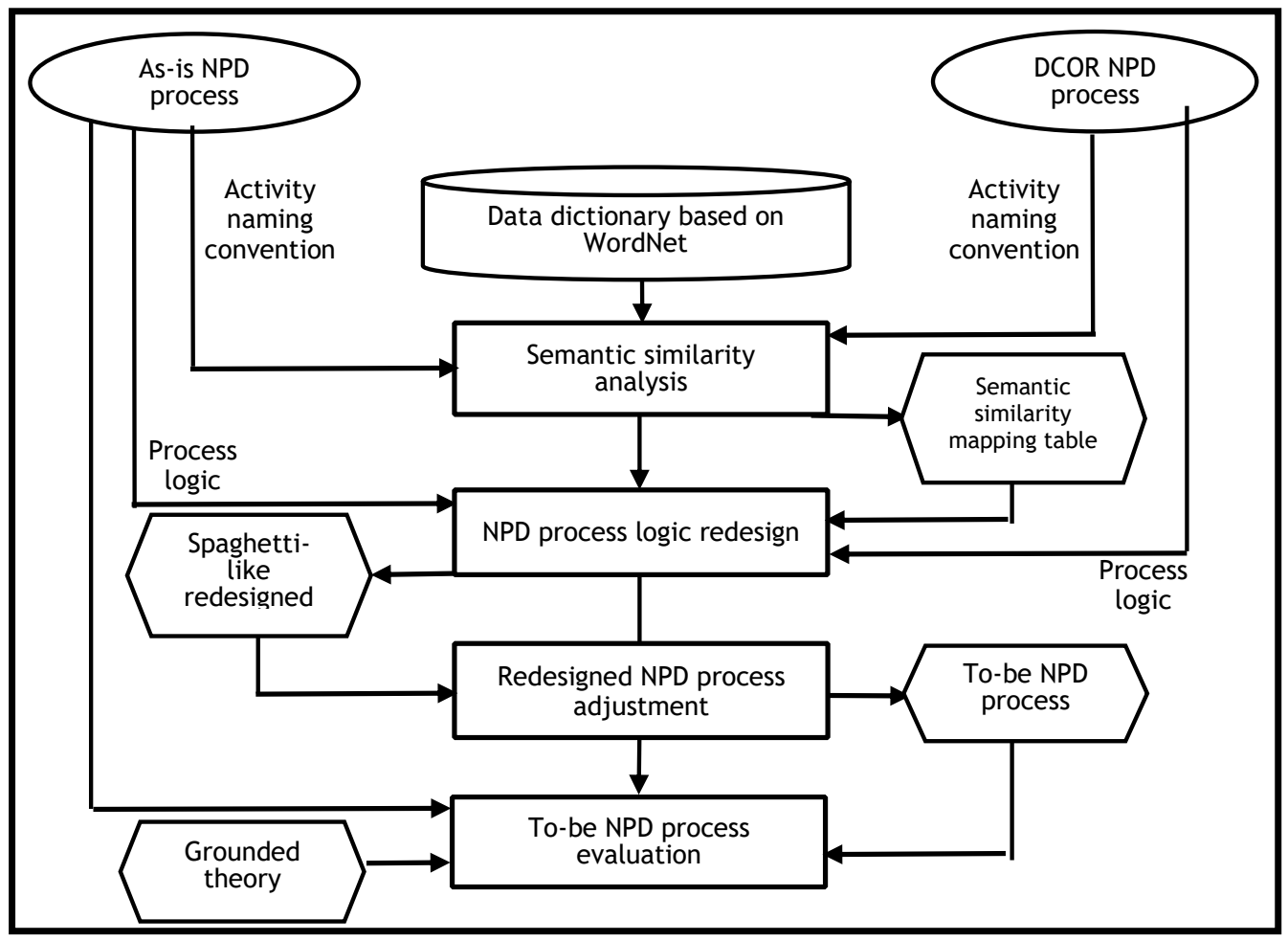

Figure 2: The proposed approach for redesigning the NPD process

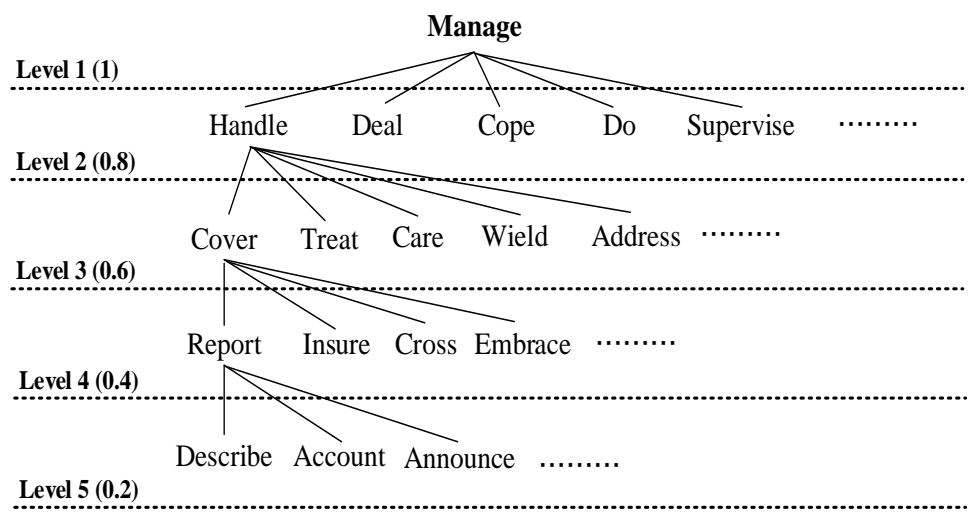

Figure 3: Semantic similarity tree of a verb or object

Afterwards, the verbs and objects in the name of activities in the as-is NPD process were retrieved and compared with those in DCOR via the constructed SSTs. The designed calculation equation is as follows:

where

$$
S S A_{\text {name }}\left(V_{i j}, O_{i j}\right)=\frac{\sum_{i=1}^{m} \sum_{j=1}^{m} S\left(V_{i,} V_{j}\right)+\sum_{i=1}^{n} \sum_{j=1}^{n} S\left(O_{i} O_{j}\right)}{\left(V_{m} * V_{n}\right)+\left(O_{m} * O_{n}\right)}
$$

$S S A_{\text {name }}\left(V_{i j}, O_{i j}\right)$ is the name of the semantic similarity between activities in the as-is and DCOR processes,

$S\left(V_{i}, V_{j}\right)$ is the semantic similarity of the verbs in the as-is process and in DCOR,

$S\left(O_{i}, O_{j}\right)$ is the semantic similarity of the objects in the as-is process and in DCOR,

$V_{m} * V_{n}$ is the number of matched verbs in activity name comparison, and 
$O_{m} * O_{n}$ is the number of matched objects in activity name comparison.

For example, an activity in as-is is P1.1 'Receive \& confirm needs'. When compared with the DCOR activity R2.1 'Receive \& validate research request', the verbs are 'Receive \& confirm' and 'Receive \& validate', resulting in an SSD match score of 1 and 0.6 . This shows as:

$S\left(V_{i}, V_{j}\right)=S\left(V_{1}=\operatorname{Re}\right.$ ceive, $V_{1}=\operatorname{Re}$ ceive $)=1$; Receive is the same word.

$S\left(V_{i}, V_{j}\right)=S\left(V_{1}=\right.$ Re ceive, $V_{2}=$ Validate $)=0.4 ;$ Receive $\rightarrow$ Undergo $\rightarrow$ Sustain $\rightarrow$ Validate.

$S\left(V_{i}, V_{j}\right)=S\left(V_{2}=\right.$ Confirm, $V_{1}=$ Re ceive $)=0.4$; Confirm $\rightarrow$ Support $\rightarrow$ Take $\rightarrow$ Receive.

$S\left(V_{i}, V_{j}\right)=S\left(V_{2}=\right.$ Confirm,$V_{2}=$ Validate $)=0.6$; Confirm $\rightarrow$ Certify $\rightarrow$ Validate.

In addition, the objects are 'Needs' and 'Research request'. The computation of $S\left(O_{i}, O_{j}\right)$ is as:

$$
\begin{aligned}
& S\left(O_{i}, O_{j}\right)=S\left(O_{1}=\text { Needs, } O_{1}=\text { Re search }\right)=0.2 ; \text { Research } \rightarrow \text { Inquiry } \rightarrow \text { Request } \rightarrow \text { Demand } \rightarrow \text { Needs. } \\
& S\left(O_{i}, O_{j}\right)=S\left(O_{1}=\text { Needs, } O_{2}=\text { Re quest }\right)=0.6 ; \text { Request } \rightarrow \text { Demand } \rightarrow \text { Needs. }
\end{aligned}
$$

Therefore, the computation of $\operatorname{SSA}\left(V_{i j}, O_{i j}\right)$ for this example is as:

$$
\begin{aligned}
& S S A_{\text {name }}\left(V_{i j}, O_{i j}\right)=\frac{\sum_{i=1}^{m} \sum_{j=1}^{m} S\left(V_{i} V_{j}\right)+\sum_{i=1}^{n} \sum_{j=1}^{n} S\left(O_{i,} O_{j}\right)}{\left(V_{m} * V_{n}\right)+\left(O_{m} * O_{n}\right)} \\
& =\frac{(1+0.4+0.4+0.6)+(0.2+0.6)}{(2 * 2)+(1 * 2)}=0.53
\end{aligned}
$$

Because different amounts of $\mathrm{I} / \mathrm{O}$ data are produced from the activities in the as-is process and in DCOR, to seek the accuracy of semantic comparison for activities this study also compared the I/O data in the activities by using the following equation:

$$
S S D_{\text {Data }}=\frac{\text { SSDinput }_{\text {Data }}+\text { SSDoutput }_{\text {Data }}}{\left(\text { Data }_{A I_{\text {ipput }}} * \operatorname{Data}_{D C O R_{\text {ipput }}}\right)+\left(\text { Data }_{A I_{\text {output }}} * \operatorname{Data}_{D C O R_{\text {output }}}\right)}
$$

where

$S S D_{\text {Data }}$ is the semantic similarity of the I/O data from an activity between the as-is process and DCOR,

SSDinput $_{\text {Data }}$ is the semantic similarity of the input data from an activity between the as-is process and DCOR,

SSDoutput $_{\text {Data }}$ is the semantic similarity of the output data from an activity between the as-is process and DCOR,

$\operatorname{Data}_{A I_{\text {input }}} * \operatorname{Data}_{D C O R_{\text {ippu }}}$ is the number of the matched input data in activity I/O comparison\, $\operatorname{Data}_{A I_{\text {oupu }}} * \operatorname{Data}_{D C O R_{\text {oupur }}}$ is the number of the matched output data in activity I/O comparison.

$$
\operatorname{SSDinput}_{\text {Data }}=\frac{\sum_{i=1}^{m} \sum_{j=1}^{n} \operatorname{Si}\left(\text { Vai }_{i}, \text { Vdcor }_{j}\right)+\sum_{i=1}^{m} \sum_{j=1}^{n} \operatorname{Si}\left(\text { Oai }_{i}, \text { Odcor }_{j}\right)}{\left(V_{m} V_{n}\right)+\left(O_{m} * O_{n}\right)}
$$

where

$\mathrm{Si}\left(\mathrm{Vai}_{i}, V_{\mathrm{V}} \mathrm{cor} \mathrm{r}_{\mathrm{j}}\right)$ is the semantic similarity of the verbs between the input data from the as-is process and DCOR,

$\mathrm{Si}\left(\mathrm{Oai}_{i}, \mathrm{Odcor}_{j}\right)$ is the semantic similarity of the objects between the input data from the as-is process and DCOR,

$V_{m} * V_{n}$ is the number of the matched verbs in input data comparison, and

$O_{m}{ }^{*} O_{n}$ is the number of the matched objects in input data comparison. 


$$
\text { SSDoutput }_{\text {Data }}=\frac{\left.\sum_{i=1}^{m} \sum_{j=1}^{n} \operatorname{So}\left(\text { Vai }_{i} \text { Vdcor }_{j}\right)+\sum_{i=1}^{m} \sum_{j=1}^{n} \operatorname{So}_{j} \text { Oai }_{i} \text { Odcor }_{j}\right)}{\left(V_{m} * V_{n}\right)+\left(O_{m} * O_{n}\right)}
$$

where

$\mathrm{So}\left(\operatorname{Vai}_{i}, \mathrm{Vdcor}_{j}\right)$ is the semantic similarity of the verbs between the output data from the as-is process and DCOR,

$\mathrm{So}\left(\mathrm{Oai}_{i} \mathrm{Odcor}_{j}\right)$ is the semantic similarity of the objects between the output data from the as-is process and DCOR,

$V_{m} * V_{n}$ is the number of the matched verbs in output data comparison, and

$O_{m}{ }^{*} O_{n}$ is the number of the matched objects in output data comparison.

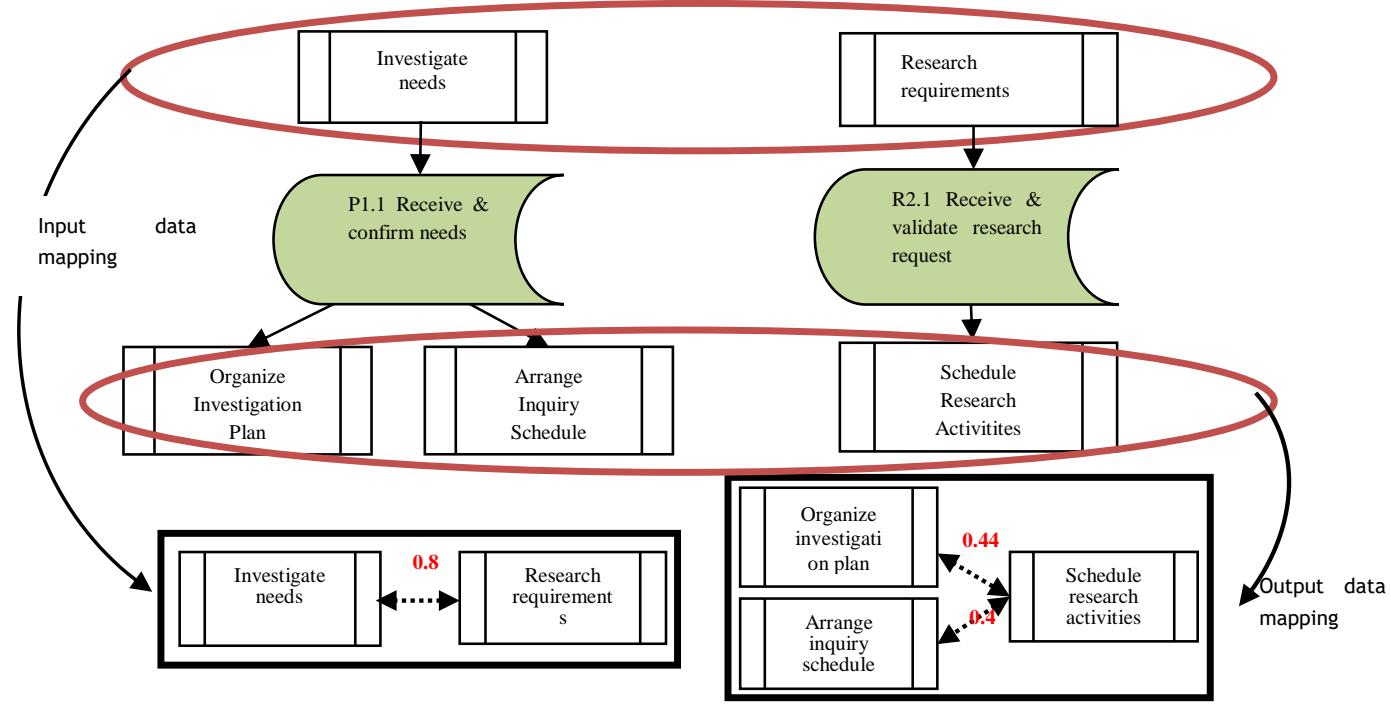

Figure 4: I/O data mapping

Figure 4 illustrates the I/O data of P1.1 and R2.1. The $S S D_{\text {Data }}$ of the I/O data from the activities are calculated as follows:

Step 1. Calculate the semantic similarities of the input data and the output data from the two activities to obtain SSDinput ${ }_{\text {Data }}$ and SSDoutput ${ }_{\text {Data }}$ respectively.

For example, the input data from the as-is activity P1.1 'Investigate needs' was first matched to the input data from the DCOR activity R2.1 'Research requirements'. Subsequently, from the SSD, the verb 'Investigate' was matched with the verb 'Research'. This semantic comparison revealed that their degree of synonymity was 0.8. The object 'Needs' was matched with the object 'Requirements', and this semantic comparison showed a degree of synonymity of 0.8 . The sum of the two scores divided by $2,(0.8+0.8) / 2=0.8$. In the same method, the output data from the as-is activity P1.1 'Organise investigation plan' and 'Arrange inquiry schedule' were matched to the output data from the DCOR activity R2.1 'Schedule research activities'. These semantic comparisons for output data showed two degrees of synonymity of 0.44 and 0.4 .

Step 2. Calculate the number of times that data were matched.

The input data from the as-is activity P1.1 'Investigate needs' and the input data from the DCOR activity R2.1 'Research requirements' has one match. The output data from P1.1, 'Organise investigation plan' and 'Arrange inquiry schedule', and the output data from R2.1, 'Schedule research activities', has two match. Therefore the number of matched times is calculated as follows:

$$
\left(\operatorname{Data}_{A I_{\text {inpu }}} * \operatorname{Data}_{D C O R_{\text {inpu }}}\right)+\left(\operatorname{Data}_{A I_{\text {outuu }}} * \operatorname{Data}_{D C O R_{\text {oupuu }}}\right)=(1 * 1)+(1 * 2)=3
$$

Step 3. Calculate the semantic similarities between the I/O data.

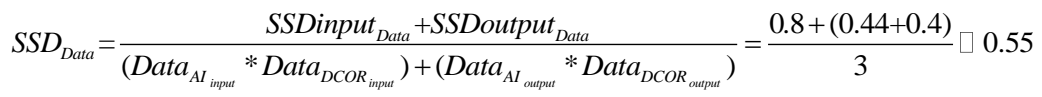


As shown in Table 2, assume that the as-is NPD process has eight activities coding from P1.1 to P1.8 and there are ten activities, including R2.1 to R2.5 and D2.1 to D2.5, in DCOR process. Besides, both the as-is and DCOR process are executed sequentially.

The numbers shown in the cells of Table 2 are the results from matching and from the aforementioned calculations, $\left(S S A_{\text {name }}(V i j, O i j), S S D_{\text {data }}\right)$. Each calculation result was entered in the corresponding table with semantic similarities. Each cell had two scores: the former score, representing the semantic matching results of the activities' names from DCOR process and the asis process, and the latter, the semantic comparison results of the I/O data from DCOR and the as-is process activities. To make the format easily identifiable, the median value was set as the threshold value. In this example, the medium values are 0.17 and 0.21 . Therefore all the numbers smaller than or equal to 0.17 and 0.21 were removed, and the numbers larger than the medium values were represented by an asterisk (Table 3 ).

Table 2: Activity mapping between as-is and DCOR with name and I/O data by SST \& SSD

\begin{tabular}{|c|c|c|c|c|c|c|c|c|}
\hline ACOR-is & $\begin{array}{l}\text { P1.1 } \\
\text { Receive and } \\
\text { confirm } \\
\text { requirement }\end{array}$ & $\begin{array}{c}\text { P1.2 } \\
\text { Applied } \\
\text { frequency }\end{array}$ & $\begin{array}{l}\text { P1.3 } \\
\text { Develop } \\
\text { plan and } \\
\text { schedule }\end{array}$ & $\begin{array}{c}\text { P1.4 } \\
\text { Research } \\
\text { resource } \\
\text { and } \\
\text { technology }\end{array}$ & $\begin{array}{c}\text { P1.5 } \\
\text { Develop } \\
\text { components }\end{array}$ & $\begin{array}{c}\text { P1.6 } \\
\text { Test } \\
\text { components }\end{array}$ & $\begin{array}{l}\text { P1.7 } \\
\text { Create } \\
\text { prototype }\end{array}$ & $\begin{array}{c}\text { P1.8 } \\
\text { Revised } \\
\text { materials } \\
\& \\
\text { technology }\end{array}$ \\
\hline $\begin{array}{c}\text { R2.1 } \\
\text { Receive and } \\
\text { validate research } \\
\text { requirement }\end{array}$ & $(0.8,0.55)$ & $(0.12,0.13)$ & $(0.12,0.13)$ & $(0.06,0.01)$ & $(0.38,0.02)$ & $(0.38,0)$ & $(0.12,0)$ & $(0.12,0)$ \\
\hline $\begin{array}{c}\mathbf{R 2 . 2} \\
\text { Manage research } \\
\text { activities }\end{array}$ & $(0.17,0.1)$ & $(0.06,0.0)$ & $(0.6,0.28)$ & $(0.51,0.38)$ & $(0,0)$ & $(0,0)$ & $(0,0.014)$ & $(0,0.014)$ \\
\hline $\begin{array}{c}\text { R2.3 } \\
\text { Receive materials } \\
\text { and technology }\end{array}$ & $(0.05,0.1)$ & $(0,0.08)$ & $(0,0.081)$ & $(0.05,0.09)$ & $(0,0.01)$ & $(0,0.03)$ & $(0,0.08)$ & $(0.75,0.8)$ \\
\hline $\begin{array}{c}\text { R2.4 } \\
\text { Verify materials } \\
\text { and technology }\end{array}$ & $(0.12,0)$ & $(0,0.04)$ & $(0,0.04)$ & $(0.35,0.52)$ & $(0.07,0.04)$ & $(0,0)$ & $(0.14,0.08)$ & $(0.74,0.57)$ \\
\hline $\begin{array}{c}\text { R2.5 } \\
\text { Transfer samples } \\
\text { and } \\
\text { documentation }\end{array}$ & $(0.06,0.2)$ & $(0,0.15)$ & $(0,0.15)$ & $(0.25,0.33)$ & $(0.02,0)$ & $(0,0)$ & $(0.12,0.22)$ & $(0.12,0.22)$ \\
\hline $\begin{array}{c}\text { D2.1 } \\
\text { Receive and } \\
\text { validate design } \\
\text { requirement } \\
\end{array}$ & $(0.75,0.12)$ & $(0.12,0)$ & $(0.12,0)$ & $(0,0)$ & $(0,0)$ & $(0.11,0.05)$ & $(0,0.028)$ & $(0,0.028)$ \\
\hline $\begin{array}{c}\text { D2.2 } \\
\text { Schedule design } \\
\text { activities }\end{array}$ & $(0.07,0.17)$ & $(0.06,0.0)$ & $(0.36,0.65)$ & $(0.08,0.4)$ & $(0,0)$ & $(0,0)$ & $(0,0)$ & $(0,0)$ \\
\hline $\begin{array}{c}\text { D2.3 } \\
\text { Develop } \\
\text { prototype }\end{array}$ & $(0,0.14)$ & $(0.11,0)$ & $(0.11,0)$ & $(0,0.02)$ & $(0.5,0.53)$ & $(0.21,0.11)$ & $(0.8,0.63)$ & $(0.12,0)$ \\
\hline $\begin{array}{l}\text { D2.4 } \\
\text { Build \& test } \\
\text { prototype }\end{array}$ & $(0,0.11)$ & $(0.08,0)$ & $(0.08,0)$ & $(0,0.24)$ & $(0,0)$ & $(0.45,0.16)$ & $(0.75,0.84)$ & $(0,0)$ \\
\hline $\begin{array}{c}\text { D2.5 } \\
\text { Associated with } \\
\text { documentation } \\
\text { and certification } \\
\text { to integration }\end{array}$ & $(0,0.07)$ & $(0.08,0.13)$ & $(0.08,0.13)$ & $(0.35,0)$ & $(0,0)$ & $(0,0)$ & $(0.25,0.28)$ & $(0,0)$ \\
\hline
\end{tabular}

Table 3: Marking mapping score greater than threshold with an asterisk

\begin{tabular}{|c|c|c|c|c|c|c|c|c|}
\hline $\begin{array}{r}\text { PS-is } \\
\text { DCQR }\end{array}$ & P1.1 & P1.2 & P1.3 & P1.4 & P1.5 & P1.6 & P1.7 & P1.8 \\
\hline R2.1 & $*$ & & & & & & & \\
\hline R2.2 & & & $*$ & $*$ & & & & \\
\hline R2.3 & & & & & & & & $*$ \\
\hline R2.4 & & & & $*$ & & & & $*$ \\
\hline R2.5 & & & & $*$ & & & & \\
\hline D2.1 & & & & & & & \\
\hline D2.2 & & $*$ & & & & & \\
\hline D2.3 & & & & & $*$ & & $*$ & \\
\hline D2.4 & & & & & & $*$ & \\
\hline D2.5 & & & & & & & $*$ & \\
\hline
\end{tabular}




\subsection{As-is NPD process logic redesign}

In the previous step, the semantics of the activities in the DCOR process and as-is process were compared. However, the sequence logic in the activities of the as-is and DCOR processes also had to be considered. Otherwise, when the matching was executed, the sequence would be wrong. Since the DCOR process was taken as the reference model for sequencing in this study, when the as-is process was matched to it, the as-is process had to follow the sequence in DCOR. Therefore, in this study, the as-is activities were redesigned according to the sequence of DCOR activities. Table 4 was constructed based on the sequence of DCOR activities and the matched as-is activities shown in 3 , i.e., the DCOR process activity R2.1 corresponded with the as-is process activity P1.1; R2.2 to P1.3 and P1.4; R2.3 to P1.8; and so on. Table 4 is the structure map of DSM of the DCOR process and the as-is process activities; the I/O relationships of related activities are also shown in Figure 5 the spaghetti graph of DSM.

Table 4: DSM structure map of the redesigned NPD process

\begin{tabular}{|c|c|c|c|c|c|c|c|}
\hline $\begin{array}{c}\text { DCOR } \\
\text { element }\end{array}$ & $\begin{array}{c}\text { As-is } \\
\text { process }\end{array}$ & $\begin{array}{c}\text { DCOR } \\
\text { element }\end{array}$ & $\begin{array}{c}\text { As-is } \\
\text { process }\end{array}$ & $\begin{array}{c}\text { DCOR } \\
\text { element }\end{array}$ & $\begin{array}{c}\text { As-is } \\
\text { process }\end{array}$ & $\begin{array}{c}\text { DCOR } \\
\text { element }\end{array}$ & $\begin{array}{c}\text { As-is } \\
\text { process }\end{array}$ \\
\hline R2.1 & P1.1 & R2.3 & P1.8 & R2.5 & P1.4 & D2.3 & P1.7 \\
\hline R2.2 & P1.3 & R2.4 & P1.4 & D2.2 & P1.3 & D2.4 & P1.7 \\
\hline R2.2 & P1.4 & R2.4 & P1.8 & D2.3 & P1.5 & D2.5 & P1.7 \\
\hline
\end{tabular}

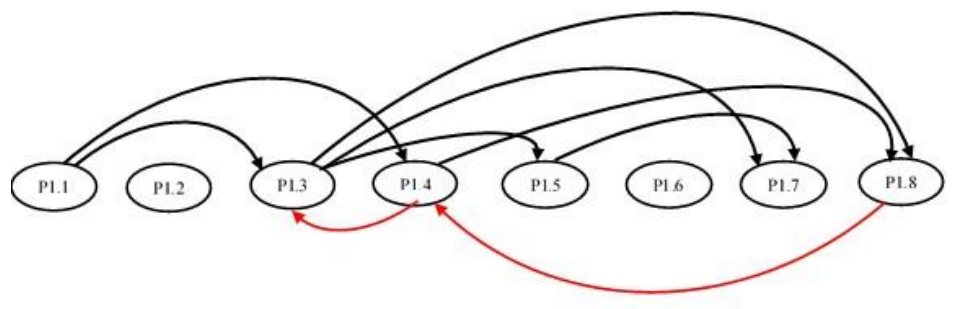

Figure 5: DSM spaghetti of the redesigned NPD process

Table 5: DSM matrix from DSM spaghetti

\begin{tabular}{|c|c|c|c|c|c|c|c|c|}
\hline Activity of P1 & $\mathrm{P} 1.1$ & $\mathrm{P} 1.2$ & $\mathrm{P} 1.3$ & $\mathrm{P} 1.4$ & $\mathrm{P} 1.5$ & $\mathrm{P} 1.6$ & $\mathrm{P} 1.7$ & $\mathrm{P} 1.8$ \\
\hline $\mathrm{P} 1.1$ & & & & & & & & \\
\hline $\mathrm{P} 1.2$ & & & & & & & & \\
\hline $\mathrm{P} 1.3$ & ${ }^{*}$ & & & $*$ & & & & \\
\hline $\mathrm{P} 1.4$ & ${ }^{*}$ & & & & & & & $*$ \\
\hline $\mathrm{P} 1.5$ & & & ${ }^{*}$ & & & & & \\
\hline $\mathrm{P} 1.6$ & & & & & & & & \\
\hline $\mathrm{P} 1.7$ & & & ${ }^{*} .8$ & & $*$ & & & \\
\hline
\end{tabular}

For example, the spaghetti graph (Figure 5) illustrates that P1.1 has two output activities (P1.3 and $\mathrm{P} 1.4)$. P1.2 has no activity connected to it, revealing that it can be an independent activity, unrelated to the sequences of other activities. P1.3 is connected to two input activity (P1.1 and $\mathrm{P} 1.4)$ and three output activities (P1.5, P1.7, and P1.8); P1.4 has two input and two output activities respectively (input: P1.4 and P1.8; output: P1.3 and P1.8). Figure 5 also shows a total of seven forward flows and two backward flows. In DSM, an 'element' represents the original process and sequence. However, if the number of the backward flows is too large, it affects the execution of other related activities. Therefore, through matching the logic sequence of as-is activities to DCOR process logic, a DSM framework based on the DCOR process was established as the main basis for redesign. Table 5 is the DSM matrix constructed based on Figure 5. In Table 5, column activities are considered to be 'from', whereas row activities are seen as 'to'. Therefore for example, the forward flows, i.e., the vertical movement, from P1.1 to P1.3 and P1.4 and a backward flow, i.e., the horizontal movement, from P1.4 to P1.3 are marked with asterisks.

\subsection{Redesigned NPD process adjustment}

To ameliorate the backward flows in redesigned NPD process, this study adopted the DSM partition method. The main purpose of partition was to improve the design process to achieve fast execution 
and reduce repetitive processes (backward flows) $[19,20]$. Therefore, according to the suggestions from DSM, to produce the to-be process, related activities in DSM matrix were grouped into sequence, parallel, and coupled tasks by adjusting the sequence of activities. Most activities were placed as forward activities, and the number of backward activities was minimised. The following are the steps to adjust the three kinds of activities for sequence, parallel, and coupled [18]:

Step 1. Find the row activities in the DSM matrix that contain no asterisks. Once found, move them to the top row, arranging them from top down. As Table 6 shows, Rows P1.1, P1.2 and P1.6 had no asterisks, so they were moved to the top of the matrix. The corresponding column activities were also moved to the most left of the matrix (Table 6(a)).

Step 2. As Table 6(a) shows, for the row activities with one or more asterisks and their corresponding the column activities without asterisks, move them to the bottom and the most right. For example, in Table 6(a), row P1.7 has two asterisks and column P1.7 has no asterisk, so it was moved to the bottom and the most right of the matrix. So did the activity P1.5 shown in Table 6(b).

Step 3. After completing Steps 1 and 2, no more could be adjusted anymore. Next, the path searching and sequence adjustment are proceeded. First, search for the remaining activities with asterisks from left to right in Table 6(c). This search terminates when repeated activities are found. For example, P1.3 $\rightarrow$ P1.8 $\rightarrow$ P1.4 $\rightarrow$ P1.3 will form a path. Then, adjust the parallel, sequential, and coupled activities. As Table 6(c) shows, P1.3 and P1.4 are a sequential set and P1.4 and P.1.8 are a coupled set.

Table 6: DSM partition for redesigned NPD process
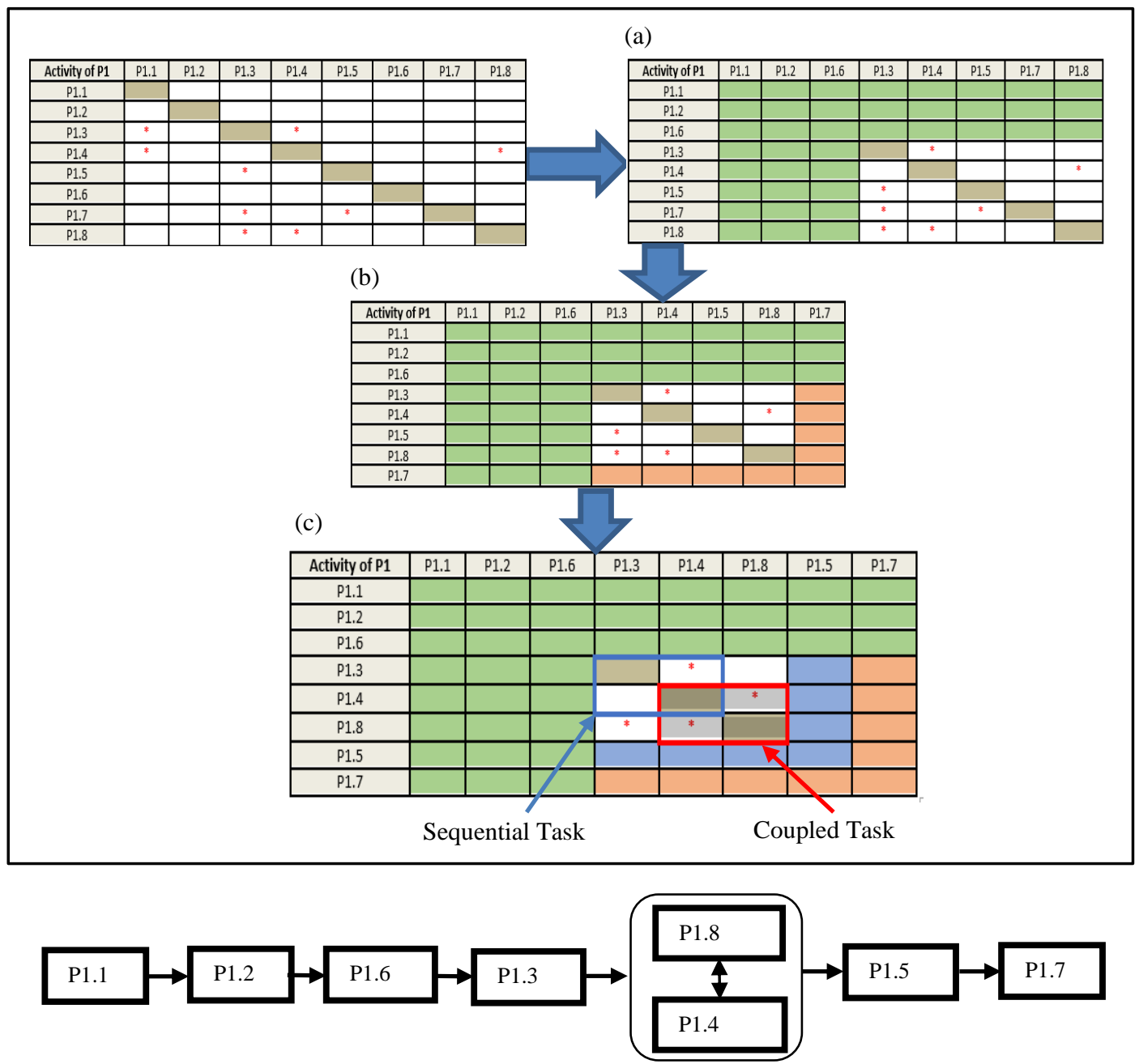

Figure 6: To-be NPD process chart 
Based on Table 6(c), the to-be NPD process chart shown in Figure 6 was obtained. As to the sequence of unmatched activities, P1.2 and P1.6, could be determined by field experts.

\subsection{To-be NPD process evaluation}

To verify that the to-be process is more effective than the current as-is process in implementation, this study adopted grounded theory (GT) for evaluation. GT is a qualitative method that gathers, organises, and analyses a wide range of concepts, integrating them into several categories of information. The GT procedures adopted by this study were based on Egan (2002). The procedures including the initiating research, data selection, initiation and ongoing data collection, data analysis, and concluding the research, are described below:

Step 1. Initiating research: The initial data were obtained through comparing the as-is and the tobe NPD processes.

Step 2. Data selection: By examining the as-is process and the to-be process, three different types of change were addressed: merge, sequence change, and topology change.

Step 3. Initiation and ongoing data collection: This study adopted the key performance indicators (KPIs) of DCOR - responsiveness, cost, reliability, flexibility, and assets - as the evaluation indicators. The researchers recorded the interview process in detail, and repeatedly crossexamined the results to identify the optimal causal relations. Open coding was produced, through which the categorisation of axial coding was inferred. The core variable was also found to complete the selective coding.

Step 4. Data analysis: After examining the collected data, repeated thoughts, concepts, or elements became increasingly clear. Experts then tagged the data with codes. GT generally has three types of code for clarifying problems step-by-step. From the three types of code, field experts analysed the degree of acceptance of the to-be process and compared it with the strength of the as-is process.

\section{AN EMPIRICAL CASE}

In this study, a real case of the development process of an unmanned aerial vehicle (UAV) was used to verify the proposed method. A total of 37 activities were involved in the as-is UAV NPD process. The DCOR NPD process was used as the reference model to redesign the as-is UAV NPD process. Figure 7 shows the as-is UAV NPD process. Its parallel activities were grouped by field experts and named in the DCOR terminology. Elements in the red blocks are sub-activities that can be operated under related activities.

\subsection{Semantic similarity analysis}

As explained in section 3, SSA was used to match the name of each activity in the as-is process with that of DCOR NPD process. The SSA results are shown as the first number in each cell of Table 7. Subsequently, the SSDs were calculated to measure the similarity of $1 / 0$ data for activities in the asis UAV and DCOR NPD processes. The SSD results are shown as the second number in each cell of Table 7 . After the median $(0.14,0.18)$ was calculated, the values of SSA and SSD smaller than the median were omitted.

\subsection{As-is UAV NPD process logic redesign}

Based on the mapping relationship of activities between the as-is UAV and DCOR NPD processes shown in Table 7, the activities of the as-is UAV NPD process were then rearranged according to the logic sequence of DCOR NPD activities. Next, the sequence of rearranged activities of the as-is UAV NPD process were converted to the DSM spaghetti shown in Figure 8.

\subsection{Redesigned UAV NPD process adjustment}

As shown in Table 8, the DSM partition was applied to the redesigned UAV NPD process. Ten activities $(C D, A n D, V D, M R, V P, A u D, A P, M S, P P$, and DIP) were sequential tasks; three activities (SD, DvP, and RV) were parallel tasks; and three activities (VM, DB, and BT) were coupled tasks. Figure 9 shows the final to-be UAV NPD process. 


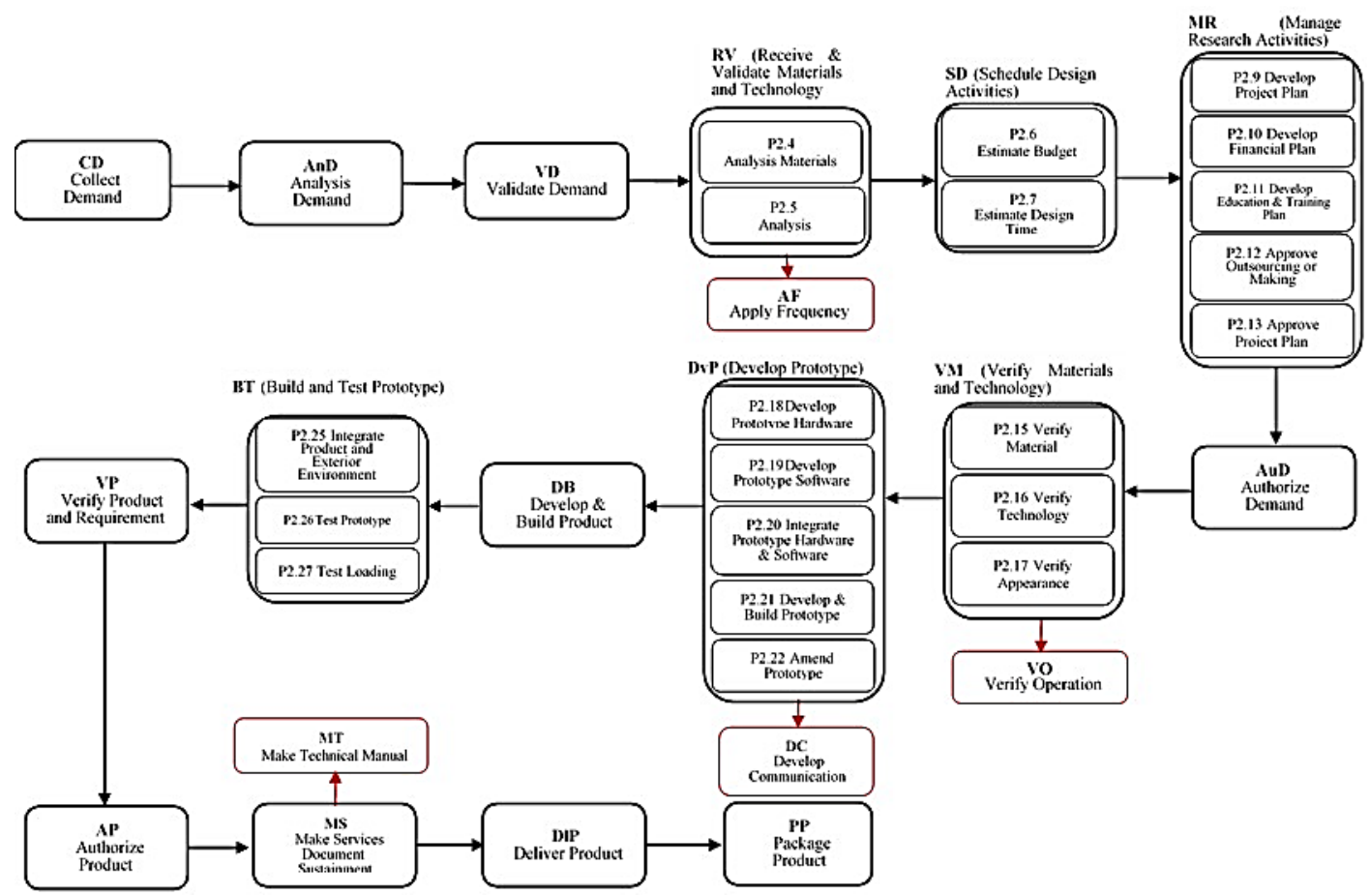

Figure 7: As-is UAV NPD process

Table 7: Semantic similarity analysis of activities in as-is UAV and DCOR NPD processes

\begin{tabular}{|c|c|c|c|c|c|c|c|c|c|c|c|c|c|c|c|c|}
\hline 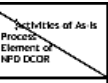 & $\begin{array}{l}\text { CD } \\
\text { Collect } \\
\text { Deemand }\end{array}$ & 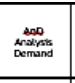 & 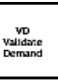 & 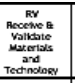 & 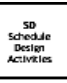 & 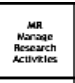 & 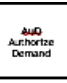 & 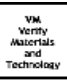 & 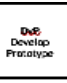 & 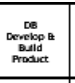 & 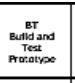 & 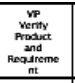 & 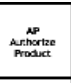 & 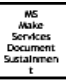 & 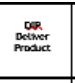 & 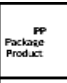 \\
\hline 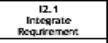 & $\begin{array}{l}0.96 \% \\
0.57 \% .7\end{array}$ & $\begin{array}{l}\text { f0.45: } \\
0.15:\end{array}$ & .01. & 10.01. & $0,01$. & $\begin{array}{l}0.04 ; \\
0.111,\end{array}$ & $\begin{array}{l}\text { 10.43: } \\
\text { a.11): }\end{array}$ & 10.01. & $.11,0 \%$. & $(0,0.04) \times$, & $\begin{array}{c}(0.05,0.0 \\
77 .)\end{array}$ & $(0.02,0)$ & $\begin{array}{c}0.06 .0 .0 \\
2 j, .0\end{array}$ & $\begin{array}{c}(0.05,0.0 \\
7) . .1\end{array}$ & $(0.02,0)$ & fo, 01. \\
\hline $\begin{array}{c}12.2 \\
\text { Docomposes } \\
\text { Regatrements }\end{array}$ & $\begin{array}{l}\text { fo.14: } \\
0.1 \%:\end{array}$ & 80.96. & $10,01$. & $\{0,01$. & 10. 01.. & $(0.01,0)$. & $\begin{array}{l}0.1 \\
0.08 i . . \\
\end{array}$ & 10. 01. & $0.05,0)$. & $(0,0.07)$, & $(0,0)$. & $(0,0) \cdot n$ & $(0,0)$, & {$[0,0)$.} & {$[0,0)$.} & fo, 01. \\
\hline $\begin{array}{c}123 \\
\text { Detrute } \\
\text { Reoustremerts }\end{array}$ & $\begin{array}{c}0.05,0.0 \\
3) . .\end{array}$ & $\begin{array}{l}10.1 \\
0.21 \% .\end{array}$ & $\begin{array}{l}\text { 10.31: } \\
0.41 ;\end{array}$ & f0.01.. & 10.01.. & $\begin{array}{l}10.2 . \\
0.04) .\end{array}$ & $\begin{array}{l}0.2 .21 .4 \\
0.04 .1\end{array}$ & 0.01. & $\begin{array}{l}10.07 \text {. } \\
0.16 \mathrm{i} .\end{array}$ & 10.01. & $\begin{array}{c}(0.08,0.0 .1 \\
2) .4\end{array}$ & $\begin{array}{c}0.03,0.11 \\
j, 1\end{array}$ & $\begin{array}{c}(0.03 .0 .0 \\
8) .\end{array}$ & $\frac{(0.08,0.1}{2) .1}$ & $\begin{array}{c}0.03 ; 0.11 \\
j .1\end{array}$ & 0.01. \\
\hline 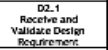 & $\begin{array}{l}0.07 .0 .0 \\
43: .0\end{array}$ & $(0,0.04) .$. & 10.01. & $\begin{array}{l}0.75 .7 . \\
0.077 .\end{array}$ & 0.211. & $\begin{array}{l}\text { 10. } \\
\text { o.11: }\end{array}$ & $\begin{array}{c}(0.04,0.0 \\
6) .1\end{array}$ & $10,01$. & $0.1 \%$ & $(0,0.06), x$ & $(0.23,0.2$ & $\begin{array}{c}8031,0.02 \\
i,-1\end{array}$ & $(0,0)$ & $(0,0)$ & $(0,0)$, & 10. 01. \\
\hline 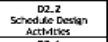 & $\begin{array}{c}0.11,0.0 \\
7), .0\end{array}$ & 10.01. & $10,0 \mid$. & $(1,0.34) .$, & . 0.13$).$ & $10,01 . x$ & 10.03: & 0.01. & $\frac{0.1,0.01}{i ; .1}$ & $(0,0.06), \pi$ & $\begin{array}{c}(0.05,0.0 \\
11 . .1\end{array}$ & $\begin{array}{c}0.3 ., 0.2 \\
31 . .2 \\
\end{array}$ & $\begin{array}{c}(0.06 .0 .0 \\
41.5\end{array}$ & $\begin{array}{c}(0.05,0.0 \\
11 . .1\end{array}$ & $\{0,0.03\} \times$ & 10.01. \\
\hline 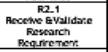 & $\begin{array}{c}0.35,0.0 \\
3):=\end{array}$ & $(0.2,0)$, & $\begin{array}{l}10.35 \text {; } \\
0.111 ;\end{array}$ & $10,01$. & (0., of. & (0.1. & $\underset{10.25,005}{, .1}$ & 10, 01.. & $(0 . .0)$ & $10,01$. & $\begin{array}{c}0.27 .0 .3 \\
y, 1\end{array}$ & $(0,0)$ & $(0,0)$ & $(0,0)$. & $(0.05,0.0$ & $10,01$. \\
\hline 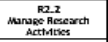 & $\begin{array}{l}0.15 . \\
0.04 \% .\end{array}$ & $\begin{array}{l}0.32 . \\
0.0 .0 \%:\end{array}$ & 10.01. & $\{0,01$. & $\begin{array}{l}0.40 \\
0.03 i . .\end{array}$ & (1,0.1): & $\begin{array}{l}10.3 \\
0.09 \% .9\end{array}$ & $10.01 .$. & $\frac{10.1,0.03}{j ; .4}$ & $(0.05,03 .$, & $\{0.1,0.091$. & $\begin{array}{c}0.1,0.03 \\
; j, 1\end{array}$ & $\begin{array}{l}(0.06,0.1 \\
2) \cdot 1\end{array}$ & $\frac{(0.11,0.0}{9)_{.4}}$ & $\frac{0.1,0.03}{; .1}$ & $10.01 . x$ \\
\hline 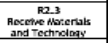 & $\begin{array}{l}0.15,0.0 \\
3) . .\end{array}$ & $(0.0 .24) .1$ & $\begin{array}{l}10.2 \\
0.033) .1 \\
0.0\end{array}$ & $(1,0.67), 1$ & $(0,0.06)$. & $\begin{array}{l}10.26 \% \\
0.29),\end{array}$ & $\begin{array}{l}80.21 . \\
0.081 . \\
8\end{array}$ & $\{0.2,0.1\}$ & $\stackrel{0.06,0.1}{1.1}$ & $(0,0.05)$, & $\frac{(0.11,0.0}{6) .4}$ & $\begin{array}{c}0.26,0.2 \\
1.1 \\
\end{array}$ & $\begin{array}{c}(0.26,0.2 \\
11 . .1\end{array}$ & $\begin{array}{c}(0.11,0.0 \\
6) .1\end{array}$ & $\underset{10.06,0.1}{1.1}$ & $\{0.01$. \\
\hline 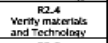 & $\begin{array}{l}10.07 .0 .0 \\
4 j \times .\end{array}$ & $\begin{array}{l}10.1 \\
0.28 ; .1 \\
\end{array}$ & 10.01. & $\{0,01$. & $(0,0.11)$, & $\frac{(0.03,0.0}{7) . .0}$ & $\begin{array}{l}0.5 .5 \\
0.25 i .1 \\
\end{array}$ & (1. 0.1). & $\begin{array}{c}0.11 .0 .0 \\
60.1\end{array}$ & $\begin{array}{l}10.1 . \\
0.08 \% .1\end{array}$ & $(0,0) . \pi$ & $(0,0) \cdot \pi$ & $(0,0)$ & {$[0,0)$} & {$[0,0)$} & $00.01 .$. \\
\hline 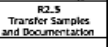 & $\begin{array}{c}0.11,0.0 \\
7), 1 .\end{array}$ & $(0.02,0)$. & 10.01. & 0.01. & $10,01 .-1$ & $\frac{(0.12,0.0}{7), 1}$ & $(0,0), x$ & 10.01. & $\begin{array}{c}0.06 .0 .0 \\
21.1\end{array}$ & $\frac{10.18,0.1}{60.1}$ & $(0,0)$, & $(0.01,1)$, & 80.24: & (10.44, & $\begin{array}{l}\text { fo.01: } \\
0.11:-\end{array}$ & 80.01. \\
\hline 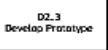 & $\frac{(0.05,0.2}{31.1}$ & $(0.04,03 .$. & $\begin{array}{l}10.2 \\
0.055)\end{array}$ & 10. 01. & $\begin{array}{l}0.12 \% \\
0.248 \mathrm{~A}\end{array}$ & {$[0,0)$.} & $\frac{(0.21,0.2}{3) .}$ & $(0.01 .$. & (1. 0.6), & $\begin{array}{l}0.45 \% \\
0.25 \% .\end{array}$ & $\begin{array}{l}\text { 10.85. } \\
0.55:=\end{array}$ & $(0.11,0.2$ & {$[0,0)$} & (10.24). & $(0,0)$. & 10.01. \\
\hline 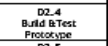 & $\begin{array}{l}10.12 . \\
0.08 \% .\end{array}$ & 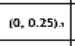 & 이. & $\begin{array}{l}10.4 . \\
0.04 \% .1\end{array}$ & . & $\begin{array}{c}(0.05,0.0 \\
21.7\end{array}$ & $\begin{array}{l}0.2 .2 \\
0.35 \% . .\end{array}$ & 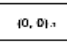 & $\begin{array}{l}0.66 \mathrm{i} \\
0.46 \mathrm{i}\end{array}$ & 80.31: & $(1,0.6)$. & $(0,0)$ & $(0.0 .25)$, & $\begin{array}{l}0.09 \\
0.03 \%,\end{array}$ & $(0,0) .$. & 10.01. \\
\hline 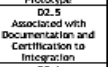 & $(0.04,0)$. & $(0.09,0.1$ & $10,01$. & $\{0,0\}$. & $\begin{array}{l}10.14 . ; \\
0.09 \%,\end{array}$ & $\{0.5,0.13\}$ & {$[0,0)$} & 10.01. & $\frac{(0.06,0.0}{21.1}$ & {$[0,0.06)$,} & $\begin{array}{l}10.05 \\
0.04) .\end{array}$ & $(0.01,0.1$ & $(0.04,0.0$ & $\begin{array}{l}10.45 \\
0.347,\end{array}$ & $(0.01,0.1$ & 10.01. \\
\hline 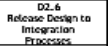 & {$[0.09,0)$.} & $\frac{10.1 ; 0.03}{; .1}$ & 10. 01. & $\{0,0\}$ & $\begin{array}{l}10.45 . \\
0.03 \% .\end{array}$ & $\{0.1,0.08\}$ & $\begin{array}{l}80.25 . \\
0.31 .\end{array}$ & 0.22. & $\frac{(0.01 .0 .0}{31) .}$ & 10.01. & $(0.25,02)$. & $\frac{10.20 .23}{i=1 .}$ & $(0,0)=$ & {$[0,0)$} & $(0,0)$, & 00.01. \\
\hline 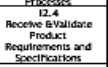 & 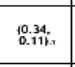 & $(0.08,0.1$ & 10.01. & 10.01. & 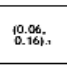 & $\begin{array}{l}00.05 \\
0.26) .\end{array}$ & $(0,0)$ & (10.37; $0.33 \%$ & 10.01. & $(0,0.02), n$ & $\{0.2,0.24\}=$ & $\begin{array}{c}0.35,0.2 \\
91.1\end{array}$ & $(0.2,0.34$ & $(0,0)$ & $(0,0) \cdot x$ & 10.01. \\
\hline 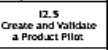 & $\begin{array}{l}0.03 \\
0.01 \% .\end{array}$ & $\left\{\begin{array}{l}0.07 \\
0.13 i\end{array}\right.$ & 10.01. & $\{0,01$. & $10,01$. & $\begin{array}{l}10.21: \\
0.11:\end{array}$ & $(0.08,0.1$ & 10.01. & $\begin{array}{l}10.27 \\
0.048 .\end{array}$ & $\begin{array}{l}10.9 \% \\
0.16 \mathrm{i} .\end{array}$ & $\begin{array}{l}10.02 \\
0.15 \%,\end{array}$ & $(0,0)$ & $\frac{10.37,0.0}{6 j . .}$ & $(0.02)$ & $(0,0)$ & 10, 01. \\
\hline $\begin{array}{l}12.6 \\
\text { Packase Produt }\end{array}$ & $\begin{array}{l}0.34 . \\
0.17 \% .\end{array}$ & $\begin{array}{c}0.1,0.13 \\
j .1\end{array}$ & $10,0.0$ & . & 10.01. & $\begin{array}{l}{[0.3 .3} \\
0.09) .\end{array}$ & $(0,0)$ & $10,01$. & $\frac{10.1 ; 0.06}{j ; .1}$ & $\begin{array}{c}10.06,0.1 \\
2) .1\end{array}$ & $\begin{array}{l}10.1 ; \\
0,05) . \\
\end{array}$ & {$[0,0) \cdot \pi$} & $(0,0)$ & $(0,0) \times$ & $(0.5,0)$ & $\{1,1\}$, \\
\hline $\begin{array}{c}12.7 \\
\text { Reciesse Produst }\end{array}$ & $\begin{array}{l}10.27 \% \\
0.048 .1\end{array}$ & $(0,0.06) \cdot$. & $10,01$. & $10,01$. & f0. ㅇ… & 10.01. & $\begin{array}{l}0.08 \\
0.21: \\
0.28\end{array}$ & 10. 01. & $\frac{10.1 ; 0.03}{; .1}$ & $\begin{array}{l}10.04, \\
0.11:\end{array}$ & $(0,0)$ & $(0,0)$. & $(0,0) \cdot \pi$ & {$[0,0) \cdot$} & $(1,0.68)$. & 10.5, 0.11 \\
\hline
\end{tabular}




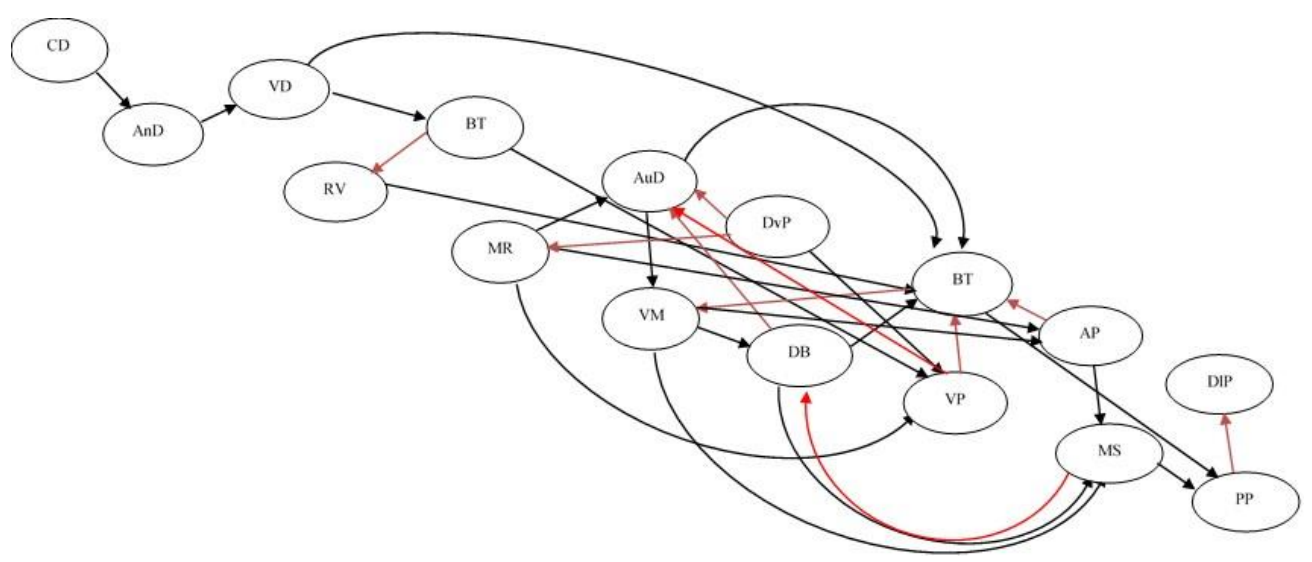

Figure 8: DSM spaghetti of redesigned UAV NPD process

Table 8: DSM partition for redesigned UAV NPD process

\begin{tabular}{|c|c|c|c|c|c|c|c|c|c|c|c|c|c|c|c|c|}
\hline $\begin{array}{l}\text { Activities } \\
\text { of to-be }\end{array}$ & $C D$ & And & VD & SD & DvP & $\mathrm{RV}$ & MR & VP & AuD & VM & DB & BT & AP & MS & PP & DIP \\
\hline$C D$ & & & & & $\mathrm{Se}$ & entia & & & & & & & & & & \\
\hline AnD & $*$ & & & & $\rightarrow$ & & & & & & & & & & & \\
\hline VD & & * & & & & & & \multicolumn{2}{|c|}{ Parallel } & & & & & & & \\
\hline SD & & & * & & & & & & 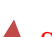 & & & & & & & \\
\hline DvP & & & & & & & & & & tet & du & & & & & \\
\hline RV & & & & * & & & & & & & & & & & & \\
\hline MR & & & & & $*$ & & & & & & Cov & oled & & & & \\
\hline VP & & & & * & $*$ & & $*$ & & & & & & & & & \\
\hline $\mathrm{AuD}$ & & & & & $*$ & & $*$ & $*$ & & & * & & & & & \\
\hline VM & & & * & & & & & & * & & & * & & & & \\
\hline DB & & & & & & & & & & * & I & & & $*$ & & \\
\hline BT & & & & & & * & & * & * & & $*$ & & & & & \\
\hline AP & & & & & & * & $*$ & & & * & & & & & 1 & \\
\hline MS & & & & & & & & & & * & * & & * & & & \\
\hline PP & & & & & & & & & & & & * & & $*$ & & \\
\hline DIP & & & & & & & & & & & & & & & * & \\
\hline
\end{tabular}

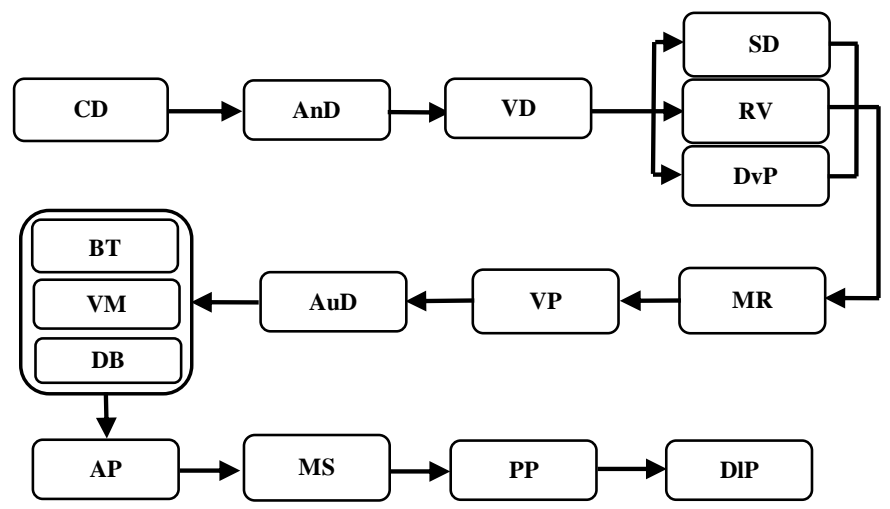

Figure 9: To-be UAV NPD process 


\subsection{To-be UAV NPD process evaluation}

In the data collection stage in GT, eight people from a UAV design industry were interviewed and we used the upper case letters ' $A$ ', ' $B$ ', ' $C$ ', and ' $D$ ' to represent the four types of interviewees: project managers, system analysts, integration engineers, and engineering assistants. Besides, a questionnaire shown in Table 9 was drafted to evaluate the effects of the changes from as-is to tobe UAV NPD process on DCOR's five KPIs. In the questionnaire, this study used:

1. ' 1 ', ' 2 ', and ' 3 ' to represent the three types of change about 'merge', 'sequence change' and 'topology change' for as-is to to-be UAV NPD processes;

2. lower case letters, ' $a$ ', ' $b$ ', ' $c$ ',,.. , to represent the questions for each specific changes of the above three types of change.

Table 9: GT questionnaire for to-be UAV NPD process evaluation

1. Merge :

a. Do you think it is appropriate if the two as-is (Figure 7) activities, 'P2.4 Analysis Materials' and 'P2.5 Analysis Technology', are represented as the to-be (Figure 9) activity 'RV Receive \& Validate Materials and Technology'? What advantages can be achieved in terms of this kind of hierarchical representation?

b. Do you think it is appropriate if the two as-is (Figure 7) activities, 'P2.6 Estimate Budget' and 'P2.7 Estimate Design Time', are represented as the to-be (Figure 9) activity 'SD Schedule Design Activities'?

C. Do you think it is appropriate if the five as-is (Figure 7) activities, 'P2.9 Develop Project Plan', 'P2.10 Develop Financial Plan', 'P2.11 Develop Education \& Training Plan', 'P2.12 Approve Outsourcing or Making' and 'P2.13 Approve Project Plan', are represented as the to-be (Figure 9) activity 'MR Manage Research Plans'?

d. Do you think it is appropriate if the three as-is (Figure 7) activities, 'P2.15 Verify Materials', 'P2.16 Verify Technology' and 'P2.17 Verify Appearance', are represented as the to-be (Figure 9) activity 'VM Verify Materials and Technology'?

e. Do you think it is appropriate if the five as-is (Figure 7) activities, 'P2.19 Develop Prototype Hardware', 'P2.20 Develop Prototype Software', 'P2.21 Integrate Prototype Hardware \& Software', 'P2.22 Develop \& Build Prototype' and 'P2.23 Amend Prototype Defectiveness', are represented as the to-be (Figure 9) activity 'DvP Develop Prototype'?

f. Do you think it is appropriate if the two as-is (Figure 7) activities, 'P2.25 Integrate Product and Exterior Environment', 'P2.26 Test Prototype' and 'P2.27 Test Loading', are represented as the to-be (Figure 9) activity 'BT Build and Test Prototype'?

2. Sequence change:

a. Must the as-is (Figure 7) activity 'RV Receive \& Validate Materials and Technology' be done before activity 'SD Schedule Design Activities'?

b. What kind of advantages can be achieved if the sequence of the as-is (Figure 7) activities 'DvP Develop Prototype' and 'MR Manage Research Activities' is reversed in the to-be process (Figure 9)? What kind of the effects would be made on project reliability, assets or flexibility in practice?

c. As shown in the to-be process (Figure 9), If the as-is (Figure 7) activity 'DvP Develop Prototype' is executed before activity 'AuD Authorize Demand', would it improve the design chain? What kind of the effects would be made on project reliability, assets and flexibility in practice?

d. What would it improve the design chain that the sequence of the as-is (Figure 7) activities 'DIP Deliver Product' and 'PP Package Product' is in the to-be process (Figure 9)? What kind of the effects would be made on project cycle time, cost, reliability, assets and flexibility in practice?

3. Topology change:

a. What do you think if the two activities 'RV Receive \& Validate Materials and Technology' and 'DvP Develop Prototype' are executed from sequentially (as-is) to concurrently (tobe)? What kind of effects would be made on project cycle time, cost, reliability and flexibility in practice?

b. What do you think if the three activities 'VM Verify Materials and Technology', 'BT Build \& Test Prototype' and 'DB Develop \& Build Product' are executed from sequentially (asis) to concurrently (to-be)? What kind of effects would be made on project cycle time, cost, reliability and flexibility in practice?

Therefore, 1cA stands for the opinion from project manager $\mathrm{A}$ to question $1 \mathrm{c}$. 
During the interview, researchers continuously collected data and organised important messages in the data to compose the open coding. Subsequently the open coding was categorised and induced into axial coding. Finally, the axial coding was integrated into the five major axials, or the five KPIs of DCOR, and became selective coding. Interview data and organised information for GT evaluation are presented in Table 10. From Table 10, the following conclusions were drawn:

1. Contents were collected from the responses to a total of 39 questions. Of these, 33 agreed that the results from the to-be UAV NPD process were superior to those of the as-is UAV NPD process, and six disagreed.

2. Among the five KPIs, 'responsiveness' and 'reliability' comprised over half of the items with the most substantial effectiveness, whereas 'assets' comprised the smallest number of improved items.

Table 10: GT results for to-be UAV NPD process evaluation

\begin{tabular}{|c|l|l|c|}
\hline $\begin{array}{l}\text { Total number of } \\
\text { interviewees } \\
\text { disagree with to-be } \\
\text { process }\end{array}$ & $\begin{array}{l}\text { Total number of } \\
\text { interviewees } \\
\text { agree with to-be } \\
\text { process }\end{array}$ & Themes of selective coding & Percentage \\
\hline & 11 & Responsiveness & $28 \%$ \\
\hline & 5 & Cost & $13 \%$ \\
\hline & 5 & Reliability & $26 \%$ \\
\hline & 2 & Flexibility & $5 \%$ \\
\hline & Assets & $\begin{array}{l}\text { There are six different opinions } \\
-10 A, 1 c B, 1 e B, 1 e C, 1 \mathrm{fB}, 3 \mathrm{aB}\end{array}$ & $15 \%$ \\
\hline
\end{tabular}

The six disagreed opinions shown in Table 10 are detailed below:

1. $1 \mathrm{CA}$ and $1 \mathrm{CB}$ presented the different opinions from project manager and system analyst to question 1c. They stated that the as-is (Figure 7) activity 'P2.12 approve outsourcing or making' should not be merged into the to-be (Figure 9) activity 'MR Manage Research Plans' because outsourcing or self-making should have be decided before the development tasks (P2.9 to P2.11).

2. $1 \mathrm{eB}$ and $1 \mathrm{eC}$ presented the different opinions from system analyst and integration engineer to question 1e. They declared that the as-is (Figure 7) activity 'P2.23 amend prototype defectiveness' should not be merged into the to-be (Figure 9) activity 'DvP Develop Prototype'. It could only be implemented after the testing tasks (P2.26 and P2.27).

3. $1 \mathrm{fB}$ presented a different opinion from system analyst to question $1 \mathrm{f}$. It was stated that the asis (Figure 7) activity 'P2.25 integrate product and exterior environment' should not be merged into the to-be (Figure 9) activity 'BT Build and Test Prototype'. It should be included in the activity 'DvP Develop Prototype'.

4. $3 \mathrm{aB}$ presented a different opinion from system analyst to question $3 \mathrm{a}$. It was stated that the two to-be (Figure 9) activities 'RV receive \& validate materials and technology' and 'DvP develop prototype' could not be parallel tasks because, in practice, materials and techniques must be determined before the prototype development.

The disagreed opinions were therefore collected and shared with other interviewers to gather more objective opinions. After discussion with the other interviewers, the following opinions were expressed about the disagreements:

1. For $1 \mathrm{CA}$ and $1 \mathrm{CB}$, the as-is (Figure 7) activity ' $\mathrm{P} 2.12$ approve outsourcing or making' including in the to-be (Figure 9) activity 'MR Manage Research Plans' indicates the determination about self-making or purchasing for the materials and components, not the entire project. Here, the project should be designated as a self-making project previously, so it implemented a lot of research and development activities for new UAV development. 
2. Although $1 \mathrm{eB}$ and $1 \mathrm{eC}$ considered that the activity ' $\mathrm{P} 2.23$ amend prototype defectiveness' could only be implemented after testing tasks, other interviewees believed that partial amending could be conducted before the completion of all testing work to save time.

3. Although $1 \mathrm{fB}$ considered that the activity 'P2.25 integrate product and exterior environment' could be included in the to-be activity 'DvP Develop Prototype', doing so has a disadvantage. In fact, when a prototype is integrated with the exterior environment before it was completed, problems such as schedule delays may occur.

4. $3 \mathrm{aB}$ emphasised that the two to-be (Figure 9) activities ' $R V$ receive \& validate materials and technology' and 'DvP develop prototype' could not be done concurrently. However, the comments from project manager $(3 \mathrm{aA})$ and integration engineer $(3 \mathrm{aC})$ believed that their concurrent implementation would not affect the development of the prototype; rather, it would make the confirmation of materials and technology more practical.

\section{CONCLUSION}

This research used a reference model, DCOR, as the target of benchmarking, not only to retain the strengths of the design chain of a company, but also to receive the benefits of benchmarking.

This NPD process redesign method provides at least three directly-applicable research contributions:

1. It provides companies with a framework for efficiently and effectively redesigning NPD process.

2. This framework provides the semantic similarity measures for the activity comparison between as-is and DCOR NPD processes. Tree-like synonyms are used, and each layer was assigned a different weight for different levels of similarity. This approach can be used not only for benchmarking, but also for other semantic-similarity searching.

3. The framework also provides a process benchmarking method which can redesign the as-is NPD process by learning the process logic of DCOR NPD process.

\section{REFERENCES}

[1] Arriaza, R.Z. 2015. Modeling the processes of the mining industry using SCOR and DCOR models. Dynamics in Logistics, 4, pp. 69-74.

[2] Weske M. 2012. Business process management architectures. in Business Process Management, Springer, Berlin, Heidelberg.

[3] Reijers, H.A., Limam, S. \& van der Aalst, W.M.P. 2003. Product-based workflow design. Journal of Management Information Systems, 20(1), pp. 229-262.

[4] Juan, Y.C. \& Ou-Yang, C. 2004. Systematic approach for the gap analysis of business process. International Journal of Production Research, 42(7), pp. 1325-1364.

[5] Supply-Chain Council. 2006. Design chain operations reference-model (DCOR), version 1.0. Pennsylvania: Supply-Chain Council.

[6] da Cunha Barbosa, G.E. \& de Souza, G.F.M. 2017. A method for defence product major overhaul analysis focusing on interfaces redesign and extended life supportability. International Journal of Production Research, 56(7), pp. 2523-2538.

[7] Lin, J.S., Ou-Yang, C. \& Juan, Y.C. 2009. Towards a standardised framework for a multi-agent system approach for cooperation in an original design manufacturing company. International Journal of Computer Integrated Manufacturing, 22(6), pp. 494-514.

[8] Juan, Y.C., Ou-Yang, C. \& Lin, J.S. 2009. A process-oriented multi-agent system development approach to support the cooperation-activities of concurrent new product development. Computers \& Industrial Engineering, 57(4), pp. 1363-1376.

[9] Lyu, J. \& Chang, L.Y. 2010. A reference model for collaborative design in mould industry. Production Planning \& Control, 21(5), pp. 428-436.

[10] Wu, W.H., Yeh, S.C. \& Fang, L.C. 2007. The development of a collaborative design chain reference model for the motorcycle industry. The International Journal of Advanced Manufacture Technology, 35(3), pp. 211-225.

[11] Sivadas Aniyan, T.S. \& Pramod, V.R. 2016. Quality function deployment in the design of custom made furnaces. International Journal of Engineering Sciences \& Research Technology, 5(7), pp. 190-195.

[12] Fellbaum, C. (ed.). 1998. WordNet: An electronic lexical database: Language, speech, and communication. Cambridge: MIT Press.

[13] Arturo, M., Eugenio, M., Teresa, M. \& Alfonso, L. 2014. Ranked WordNet graph for sentiment polarity classification in Twitter. Computer Speech \& Language, 28(1), pp. 93-107.

[14] Meng, L., Huang, R. \& Gu, J. 2013. A review of semantic similarity measures in WordNet. International Journal of Hybrid Information Technology, 6(1), pp. 1-12.

[15] Gao, J.-B., Zhang, B.-W. \& Chen, X.-H. 2015. A WordNet-based semantic similarity measurement combining edge-counting and information content theory. Engineering Applications of Artificial Intelligence, $39(1)$, pp. 80-88. 
[16] Zhou, Z., Wang, Y. \& Gu, J. 2008. New model of semantic similarity measuring in WordNet. 3rd International Conference on Intelligent System and Knowledge Engineering, pp. 256-261.

[17] Patwardhan, S., Banerjee, S. \& Pedersen, T. 2003. Using measures of semantic relatedness for word sense disambiguation. Proceedings of 4th International Conference on Computational Linguistics and Intelligent Text Processing and Computational Linguistics, pp. 1-17.

[18] Yassine, A.A. 2004. An introduction to modeling and analyzing complex product development processes using the design structure matrix (DSM) method. Italian Management Review, 51(9), pp. 1-17.

[19] Pektas, S.T. \& Pultar, M. 2006. Modelling detailed information flows in building design with the parameter-based design structure. Design Studies, 27(1), pp. 99-122.

[20] Lambe, A.B. \& Martins, Joaquim, R.R.A. 2012. Extensions to the design structure matrix for the description of multidisciplinary design, analysis, and optimization processes. Struct. Multidisc. Optim., 46(2), pp. 273-284.

[21] Glasser, B. \& Strauss, A. 1967. The Discovery of Grounded Theory-Strategy for Qualitative Research, Aldine Transaction.

[22] Corbin, J. \& Strauss, A. 1990. Grounded Theory Research: Procedures, Canons, and Evaluative Criteria., Qualitative Sociology, 13(1), PP. 1-21.

[23] Egan, T.M. 2002. Grounded theory research and theory building. Advances in Developing Human Resources, 4(3), pp. 277-295.

[24] Hussein, M.E., Hirst, S., Salyers, V. \& Osuji, J. 2014. Using grounded theory as a method of inquiry: Advantages and disadvantages. The Qualitative Report, 19(27), pp. 1-15.

[25] Harry, B., Sturges, K.M. \& Klingner, J.K. 2005. Mapping the process: An exemplar of process and challenge in grounded theory analysis. Educational Researcher, 34(2), pp. 3-13.

[26] Singh, N. \& Krishnan, V.R. 2005. Towards understanding transformational leadership in India: A grounded theory approach. The Journal of Business Perspective, 24(6), pp. 559-575. 